Saudi Journal of Business and Management Studies Abbreviated Key Title: Saudi J Bus Manag Stud ISSN 2415-6663 (Print) |ISSN 2415-6671 (Online) Scholars Middle East Publishers, Dubai, United Arab Emirates Journal homepage: http://scholarsmepub.com/sjbms/

Original Research Article

\title{
Analysis of Regional Financial Management and Regional Finacsial System in Central Sulawesi, Indonesia
}

\author{
Margretha Elisabeth Jessy Wagey ${ }^{1 *}$, Djayani Nurdin ${ }^{2}$, Suparman $^{2}$, Kahar $^{2}$ \\ ${ }^{1}$ Department of Accounting, Panca Bhakti School of Economics of Palu, City of Palu, Central Sulawesi, Indonesia \\ ${ }^{2}$ Faculty of Economics, Tadulako University, Jl. Soekarno-Hatta KM.9, Tondo, Mantikulore, City of Palu, Central Sulawesi, Indonesia
}

DOI: $10.36348 /$ sjbms.2020.v05i04.004 $\quad$ | Received: 04.11.2019| Accepted: 11.11 .2019 | Published: 30.04 .2020

*Corresponding author: Margretha Elisabeth Jessy Wagey

\section{Abstract}

This study aimed to analyze the regional financial management and regional financial systems of the Central Sulawesi regional government. The type of research is a descriptive quantitative study which was carried out in the Regional Organization of Regency/City in Central Sulawesi (OPD). The sample regencies/cities are: 1) Palu City, 2) Buol Regency, 3) Tojo Una-Una Regency, 4) Morowali Regency, 5) Banggai Regency. For each OPD in each regency/city, 3 respondents were chosen, namely the head of OPD, PPTK (Financial Officer) and Treasurer. Research variables are regional financial management and implementation of regional financial information systems. The results of research show that regional financial management in the Central Sulawesi Regional Government has been good, but it still needs improvement in terms of the use of expenditure in shortest time possible and control by the DPRD. The implementation of the regional government financial system in Central Sulawesi was good for all principles, namely efficiency, effective, transparent, accountable, auditable.

Keywords: Regional Financial Management, Regional Financial System, Public Services.

Copyright @ 2020: This is an open-access article distributed under the terms of the Creative Commons Attribution license which permits unrestricted use, distribution, and reproduction in any medium for non-commercial use (NonCommercial, or CC-BY-NC) provided the original author and source are credited.

\section{INTRODUCTION}

Indicators of regional autonomy success are an increase in public services, better community welfare, an increasingly democratic life, justice, equity, and harmonious relations between central government and the regions and between regions [1]. This situation will only be achieved if the region can manage its government, one of which is the management of financial administration. A good financial management system for all regencies/cities in Central Sulawesi Province has benefited the effectiveness of public services by providing targeted services, improving the quality of public services, low service costs due to the loss of inefficiency and savings in the use of resources, more expenditure allocation oriented to the public interest, and increasing public spending as the root of the implementation of public accountability.

Regional financial management in Central Sulawesi Province has been running in accordance with the regulatory guidelines and have implemented a regional financial information system, but the regional financial performance has not been running optimally due to the low independence of the region because of limited sources of Local Revenue, especially those that are sourced from taxes and user charges, so that the hopes of the Central Sulawesi provincial government to optimize public services have not performed as expected.

There are still several interesting phenomena to be observed in governments, for example, corruption in Indonesia both at the central level and at the regional level in the reformation era, so that the community will not believe in financial management and government performance. Corruption presents a serious challenge to regional development, and good governance. Decentralization and regional autonomy have implications for the shift of central power to the regions and between institutions in the regions [2]. Corruption 
occurs because there are differences or inconsistencies of regulations issued by the central and regional governments. Regional autonomy is basically given to the regions so that regional governments can improve the efficiency, effectiveness and accountability of regional governments to achieve good governance [3].

Financial management and regional assets managed by the regional government can be in the form of money, securities, receivables, goods, and other rights that can be valued with money, including assets that are separated in regional companies which still need to be optimized, so that it can be utilized for the improvement in public services. Regional financial information systems in several regions in Indonesia are sometimes still constrained by less professional human resources, so that when a problem occurs in the system, comprehensive financial management is still stagnant [4]. Implementation of financial performance is not yet optimal so that the impact on public services is not optimal. These conditions occur in many regional governments in Indonesia.

This study aimed to analyze the regional financial management and regional financial systems of the Central Sulawesi regional government.

\section{MATERIALS AND METHOD \\ Research Type}

The type of research is a descriptive quantitative study which was carried out in the Regional Organization of Central Sulawesi (OPD) in 2018.

\section{Population and Sample}

The population of this study was the entire Regional Organization (OPD) in 13 regencies/cities in Central Sulawesi. Determination of the sample size in this study used the purposive sampling method with several criteria:

- It is not Expansion Regency/City because main Regency/City has better capabilities in terms of regional financial management, implementation of regional financial information systems, financial performance and quality of public services.

- The selected OPDs are offices and agencies outside the subdistrict and village area, with the consideration that the OPD sample has a relatively higher regional budget compared to the subdistrict and village area, so it requires better regional financial management.

Based on the criteria used, the sample regencies/cities are: 1) Palu City, 2) Buol Regency, 3) Tojo Una-Una Regency, 4) Morowali Regency, 5) Banggai Regency. For each OPD in each regency/city, 3 respondents were chosen, namely the head of OPD, PPTK (Financial Officer) and Treasurer, while from the service user, 3 respondents were chosen who got direct services from each OPD.

\section{RESEARCH VARIABLE}

- Regional financial management means regional government manages the regional finance with the principles of accountability, able to meet financial obligations, honesty, effectiveness, efficiency, and control.

- Implementation of Regional Financial Information Systems is a set of integrated applications to improve the effectiveness of the regional financial management based on the principles of efficiency, economic, effective, transparent, accountable and auditable

\section{DATA COLLECTION TECHNIQUE}

Data collection techniques, namely: 1) Observation was performed by collecting data through direct observation and initial data collection such as the number of OPDs in the Central Sulawesi Government, 2) Interview with the Head of OPD 3) Distribute questionnaires to respondents in order to determine on variables to be examined.

\section{DATA ANALYSIS}

Data analysis was performed in a descriptive way by using SPSS to obtain an overview of Regional Financial Management and Financial System Implementation in Central Sulawesi Government.

\section{RESULTS}

Table-1: Descriptive Analysis of Characteristics of Respondent

\begin{tabular}{|l|l|l|l|}
\hline Characteristic & Category & $\mathbf{n}$ & \% \\
\hline \multirow{4}{*}{ Gender } & Male & 112 & 44.8 \\
\cline { 2 - 4 } & Female & 138 & 55.2 \\
\hline \multirow{5}{*}{ Age } & $<20$ years old & 62 & 24.8 \\
\cline { 2 - 4 } & $20-30$ years old & 88 & 35.2 \\
\cline { 2 - 4 } & $31-40$ years old & 50 & 20.0 \\
\cline { 2 - 4 } & $41-50$ years old & 30 & 12.0 \\
\cline { 2 - 4 } & $>50$ years old & 20 & 8.0 \\
\hline \multirow{5}{*}{ Education Level } & Doctoral & 20 & 8.0 \\
\cline { 2 - 4 } & Bachelor & 80 & 32.0 \\
\cline { 2 - 4 } & Master & 35 & 14.0 \\
\cline { 2 - 4 } & Diploma & 65 & 26.0 \\
\cline { 2 - 4 } & High School & 50 & 20.0 \\
\hline
\end{tabular}

Table 1 shows that most respondents were female with a percentage of $55.2 \%$ and male of $44.8 \%$. The respondents aged $20-30$ years of $35.2 \%, 31-40$ years of $20 \%,<20$ years of $24.8 \%, 41-50$ years of $12 \%$ and $>50$ years of $8 \%$. Majority of respondents were bachelor of $32 \%$, diploma of $26 \%$, and high school graduated of $20 \%$. 
Table-2: Regional Finansial Management Variable

\begin{tabular}{|c|c|c|c|}
\hline No & Indicator & Mean & Stdev \\
\hline \multicolumn{4}{|c|}{ Accountability } \\
\hline 1 & Financial accountability of the Regional Government to the Central Government & 4.232 & 0.802 \\
\hline 2 & Financial accountability of the Regional Government to DPRD & 3.765 & 1.060 \\
\hline 3 & Financial accountability of the Regional Government to the Regional Head & 4.390 & 0.725 \\
\hline 4 & Financial accountability of the Regional Government to the general public & 4.203 & 0.729 \\
\hline 5 & $\begin{array}{l}\text { Accountability for effective validity to safeguard regional financial wealth and } \\
\text { goods }\end{array}$ & 4.213 & 0.693 \\
\hline 6 & $\begin{array}{l}\text { Accountability for effective procedures for safeguarding regional financial } \\
\text { wealth and goods }\end{array}$ & 4.235 & 0.660 \\
\hline 7 & Prevent regional financial waste & 4.219 & 0.667 \\
\hline 8 & Prevent misappropriation of regional finances & 4.359 & 0.674 \\
\hline 9 & Ensure that all income is legal and comes from clear sources & 4.403 & 0.704 \\
\hline 10 & Ensure that all income is legal and appropriate for its use & 4.194 & 0.685 \\
\hline \multicolumn{4}{|c|}{ Able to meet finansial obligation } \\
\hline 11 & $\begin{array}{l}\text { Regional finance must be arranged and managed in such a way as to be able to } \\
\text { pay off all its obligations }\end{array}$ & 4.305 & 2.947 \\
\hline 12 & Able to pay off predetermined short-term financial obligations & 4.356 & 0.732 \\
\hline 13 & Able to pay off predetermined medium-term financial obligations & 4.048 & 0.683 \\
\hline 14 & Able to pay off predetermined long-term loan financial obligations & 4.016 & 0.660 \\
\hline \multicolumn{4}{|c|}{ Honesty } \\
\hline 15 & Regional financial management must be assigned to honest employees & 4.305 & 0.750 \\
\hline 16 & Regional financial management must be assigned to trusted employees & 4.378 & 0.714 \\
\hline 17 & Regional financial management must be assigned to capable employees & 4.308 & 0.685 \\
\hline \multicolumn{4}{|c|}{ Effectiveness and efficiency } \\
\hline 18 & $\begin{array}{l}\text { Procedures for managing regional finances to be planned to achieve regional } \\
\text { government goals }\end{array}$ & 4.338 & 0.660 \\
\hline 19 & $\begin{array}{l}\text { Procedures for managing regional finances to be performed to achieve regional } \\
\text { government goals }\end{array}$ & 4.317 & 0.649 \\
\hline 20 & Use of expenditure as low as possible & 4.022 & 2.444 \\
\hline 21 & Use of expendinture in the shortest time possible & $\mathbf{3 . 7 8 7}$ & 0.846 \\
\hline \multicolumn{4}{|c|}{ Control } \\
\hline 22 & Control of the regional financial management officers & 4.114 & 0.686 \\
\hline 23 & Control by DPRD & 3.721 & 0.821 \\
\hline 24 & Control by supervisors & 4.086 & 0.697 \\
\hline
\end{tabular}

Table 2 shows that regional finance management in the Central Sulawesi Government was in good condition, but it still needs to be improved in terms of the use of expenditure in the shortest time possible and control by the DPRD.

Table-3: Implementation of Regional Financial Information Systems in Central Sulawesi

\begin{tabular}{|c|c|c|c|}
\hline No & Implementation of regional financial information systems & Mean & Stdev \\
\hline \multicolumn{4}{|c|}{ Efficiency Principle } \\
\hline 25 & Efficient use of direct expenditure & 4.257 & 0.678 \\
\hline 26 & Efficient use of indirect expenditure & 4.171 & 0.620 \\
\hline \multicolumn{4}{|c|}{ Effective Principle } \\
\hline 27 & Effective use of direct expenditure & 4.232 & 0.634 \\
\hline 28 & Effective use of indirect expenditure & 4.178 & 0.559 \\
\hline \multicolumn{4}{|c|}{ Transparency Principle } \\
\hline 29 & Transparency use of direct expenditure & 4.263 & 0.666 \\
\hline 30 & Transparency use of indirect expenditure & 4.219 & 0.691 \\
\hline \multicolumn{4}{|c|}{ Accountable Principle } \\
\hline 31 & Accountable use of direct expenditure & 4.260 & 0.645 \\
\hline 32 & Accountable use of indirect expenditure & 4.194 & 0.621 \\
\hline \multicolumn{4}{|c|}{ Auditable Principle } \\
\hline 33 & Auditable use of direct expenditure & 4.197 & 0.612 \\
\hline 34 & Auditable use of indirect expenditure & 4.175 & 0.596 \\
\hline
\end{tabular}


Table 3 shows that the implementation of the regional government financial system in Central Sulawesi was included in good category for all principles, namely efficiency, effective, transparent, accountable, auditable.

\section{DISCUSSION}

Regional Financial Management and implementation of regional financial management guidelines had a direct influence on financial administration services, with the implementation of these guidelines, it is expected to provide satisfaction to the public or providers of goods/services, regional government must be able to draw up a routine expenditure budget before the budget year. So that for the implementation of various activities in the following year, the allocation of expenditure can be determined, there is a sense of responsibility on human resources in order to realize the vision and mission of the financial department; there is leadership motivation in supporting the performance of financial administration officers; there are standard management mechanisms from the planning, implementation, to accountability stages of financial management.

The results of this study are supported by Government Regulation Number 56 of 2005 on Regional Financial Information Systems, regional government is obliged to develop financial management and utilize information technology to improve the ability in order to manage regional financial performance and provide regional financial information to public services. One form of utilizing information technology is the use of software as a tool in the regional accounting and financial system. A good financial management system can manage regional finances accurately, timely, transparently and accountably [5].

Other studies show that financial management accountability had a positive and significant influence on the performance of the Bengkulu Province SKPD [6]. Accountability in financial management had positive and significant relationship on regional government performance [7]. The implementation of accountability and transparency causes great control from the community so that government managers will work in accordance with existing provisions and be able to produce good government performance [8]. Regulation that supports the regional financial system on the quality of public services is Government Regulation Number 65 of 2010 on Regional Financial Information Systems which obliges Regional Government to develop and utilize information technology in order to improve the quality of public services.

The results of study by Lerly [9] which stated that the better the implementation of the regional financial information system, the better the performance of the SKPD [9]. Other studies show that the regional financial information system and internal control had been implemented well by the SKPD, and employees in the SKPD had good competence to carry out their duties and functions, so that the financial performance of the Sigi Regency SKPD was better [10]. The results of research by Mahmudi[11] which stated that the Regional Government Financial system is very important, because after all the good budget planning, if there is no adequate financial system in the implementation stage, many plan will not achieved[11].

The results of the study are in line with other studies which inform that an effective regional financial accounting system will produce quality financial statement information [12]. The regional financial system provides a positive and significant influence on the quality of financial statements, thus if the regional financial system is implemented well, the quality of the financial statements produced will also be better $[13,14]$.

\section{CONCLUSION}

Regional financial management in the Central Sulawesi Regional Government has been good, but it still needs improvement in terms of the use of expenditure in shortest time possible and control by the DPRD. The implementation of the regional government financial system in Central Sulawesi was good for all principles, namely efficiency, effective, transparent, accountable, auditable.

\section{CONFLICT OF INTEREST}

There was no conflict of interest in the preparation and completion process of this research.

\section{ACKNOWLEDGEMENTS}

The authors would like to express their gratitude to the Chief of STIE PANCA BAKTI PALU. The researchers also express their gratitude to other parties supporting this research to be fully completed.

\section{REFERENCES}

1. Wekan, R.J., (2019). The Impacts of Fiscal Decentralization on Economic Growth and Social Welfare in Maluku Province. JBMI J. Bisnis Manaj. Dan Inform. 15, 291-304. https://doi.org/10.26487/jbmi.v15i3.4818

2. Hastuti, P., (2018). Desentralisasi Fiskal Dan Stabilitas Politik Dalam Kerangka Pelaksanaan Otonomi Daerah Di Indonesia. Simp. Nas. Keuang. Negara, 784-799.

3. Sobri, K.M. (2017). The Integration of Good Governance in Effectiveness of Regional Autonomy Implementation. Am. J. Appl. Sci. 14, 90-97. https://doi.org/10.3844/ajassp.2017.90.97 
4. Pratama, S.Y. (2017). Evaluasi Penerapan Sistem Informasi Manajemen Keuangan Daerah (Simda) Pada Biro Keuangan Sekretariat Daerah Provinsi Kalimantan Timur. J. Adm. Reform JAR 4, 153169.

5. Nurhayati. (2017). Analisis Teori Transparansi Pengelolaan Keuangan Daerah di Indonesia. Trias Polit. 1, 36-54.

6. Auditya, L., Lismawati, Husaini. (2013). Analisis Pengaruh Akuntabilitas Dan

7. Ismiarti. (2013). Analisis Inplementasi Sistem Pengendalian Intern Pemerintah, Akuntabilitas dan Transparansi Terhadap Kinerja Pemerintah. Universitas Brawijaya, Malang.

8. Werimon, Simson, Ghozali, I., Nasir. (2007). Pengaruh Partisipasi Masyarakat dan Transparansi Kebijakan Publik Terhadap Hubungan Antara Pengetahuan Dewan Tentang Anggaran Dengan Pengawasan Keuangan Daerah (APBD). Simposium Nasional Akuntansi, Makassar.

9. Lerly, Novita. (2016). Pengaruh Pengawasan Intern, Perencanaan, dan Pelaksanaan Sistem
Akuntansi Keuangan Daerah Terhadap Kinerja SKPD Pemerintaham Daerah Kabupaten Sigi. Universitas Tadulako, Palu.

10. Marjoni, Amir, A.M., Kahar, A. (2018). Pengaruh Penerapan Sistem Informasi Keuangan Daerah, Pengendalian Intern, Dan Kompetensi Sumber Daya Manusia Terhadap Kinerja Keuangan SKPD Kabupaten Sigi. J. Kat. 6, 63-74.

11. Mahmudi. (2016). Manajemen Keuangan Daerah. Erlangga, Jakarta.

12. Ratifah, R. (2012). Komitmen Organisasi Memoderasi Pengaruh Sistem Akuntansi Keuangan Daerah terhadap Kualitas Laporan Keuangan. Trikonomika, 11, 29-39.

13. Wati, K.D., Nyoman Trisna Herawati, S.A., Ni Kadek Sinarwati, S., (2014). Pengaruh Kompetensi SDM, Penerapan SAP, dan Sistem Akuntansi Keuangan Daerah Terhadap Kualitas Laporan Keuangan Daerah. JIMAT J. Ilm. Mhs. Akunt. Undiksha 2.

14. Transparansipengelolaan Keuangan Daerah Terhadap Kinerjapemerintah Daerah. J. Fairness 3, 21-41. 